\title{
EFFECT OF POTASSIUM ON THE CHERRY TOMATO GROWTH AND NUTRITION IN HYDROPONIC SYSTEM
}

\author{
CRESCIMENTO E NUTRIÇÃO DE PLANTAS DE TOMATEIRO CEREJA EM \\ SISTEMA HIDROPÔNICO, SOB DOSES DE POTÁSSIO
}

\author{
Janini Tatiane Lima Souza MAIA ${ }^{1}$; Hermínia Emília Prieto MARTINEZ ${ }^{1}$; \\ Paulo Roberto CECON $^{2}$; Carla do Carmo MILAGRES ${ }^{1}$; Junia Maria CLEMENTE ${ }^{1}$ \\ 1. Department of Fitotecnia, Federal University of Viçosa, Viçosa, MG, Brazil. carlacmilagres@ yahoo.com.br; 2. Department of \\ Estatística, Federal University of Viçosa, Viçosa, MG, Brazil.
}

\begin{abstract}
Potassium has a great impact on plant growth. It regulates synthesis reactions and participates in the translocation of photoassimilates, cell elongation, and enzymatic reactions related to photosynthesis, respiration, synthesis of starches, proteins, and lignin. The objective of this study was to characterize the growth of cherry tomato in hydroponic system under increasing potassium doses. The experiment was arranged in a completely randomized design, with four replications. The treatments consisted of different doses of potassium $\left(6,8,10\right.$ and $12 \mathrm{mmol} \mathrm{L}^{-1}$ ) evaluated at 26, 41, 56, 71, 86 and 101 DAT (days after transplanting). Accumulation of dry mass of leaves, stems, roots, flowers, and fruits; leaf area; number of flowers and fruits; length and volume of roots were determined at each evaluation time. The physiological indices studied were: relative growth rate, leaf area index and ratio, net assimilation rate, root-shoot ratio, and nutrient accumulation in leaves, stems, and roots. Potassiumdoses between 6 and $12 \mathrm{mmol} \mathrm{L}^{-1}$ had no influence on the growth of the cherry tomato. The relative growth rate has gradually decreased over the evaluation period. Accumulation of nitrogen, phosphorus, potassium, calcium, magnesium, and sulfur in the leaves peaked at 101 DAT.
\end{abstract}

KEYWORDS: Solanum lycopersicum L. Nutrient solution. Growth analysis. Subirrigation.

\section{INTRODUCTION}

Fruit vegetables have been gaining ground in the past years, and tomato is well suited to hydroponic systems (FERNANDES et al., 2002; GENUNCIO et al., 2010). Among tomato species, the demand of cherry tomato varieties has increased, gaining greater consumer acceptance. The cherry tomato market value is twice as high as that of common tomatoes (ARAUJO et al., 2013). This demand has raised the number of researches aimed at this tomato group (GOMES et al., 2011; ROCHA, 2009; RODRIGUES et al., 2008; SANGTARASHANI et al., 2013; SANTOS et al., 2016).

Tomato has a good response to fertilization, thus, nutritional deficiencies or excesses can influence fruit yield and quality. Several studies on macronutrients have demonstrated the importance of potassium $(\mathrm{K})$ to the physiological function of tomato. In plants, $\mathrm{K}$ acts by regulating synthesis reactions (TAIZ; ZEIGER, 2013) and participating in the translocation of photoassimilates, cell elongation, and enzymatic reactions related to photosynthesis, respiration, synthesis of starches, proteins, and lignin (BARRETO; BEZERRA
NETO, 2000; COSTA et al., 2001; MARENCO; LOPES, 2005).

The growth analysis quantifies dry matter accumulation sequentially and allows us to describe and interpret the development of a particular species or variety under the conditions of cultivation chosen (HUNT, 1990). It is a suitable tool to evaluate the impact of nutrients on plant growth. The leaf area determines the accumulation of dry matter, plant metabolism, photosynthetic potential, yield and quality of the crop (JORGE; GONZALEZ, 1997). The accumulation of total dry matter and dry matter of parts of the plant, along with the increase in leaf area, are quantified as a function of time. These data contribute to the estimation of physiological indices such as relative growth rate, net assimilation rate, and leaf area ratio, among others (BENINCASA, 2003). These indexes allow the evaluation of the extent to which biotic or abiotic stresses, in this case the availability of $\mathrm{K}$, affect the speed of growth and carbon assimilation by plants, as well as the evolution of the cover of the cultivation area and consequently the interception of light.

From the foregoing, therefore, this study aimed to characterize the growth of cherry tomatoes in a hydroponic system under increasing $\mathrm{K}$ dose. 


\section{MATERIAL AND METHODS}

The study was carried out in greenhouse at the Department of Fitotecnia of the Federal University of Viçosa. The experiment was conducted with long life hybrid mini tomato Sindy (Sakama) in $1 / 2$ ionic strength nutrient solution described by Fernandes et al., (2002). Seeds were sown in $5 \times 5 \times 3.8 \mathrm{~cm}$ phenolic foam. The seedlings were irrigated with the nutrient solution to saturate the substrate once a day, after 6:00 p.m. Seedlings with 3-5 true leaves were transplanted to subirrigation system containing expanded clay, at the spacing of $0.3 \mathrm{~m}$ between plants and one row per trough, totaling 10 plants per plot.

The experimental plots consisted of $0.85 \mathrm{~m}$ wide asbestos cement rails in the upper part; $0.60 \mathrm{~m}$ wide at the base; $0.20 \mathrm{~m}$ high and $3.75 \mathrm{~m}$ long, waterproofed with asphalt paint, with the ends closed and filled with expanded clay. The nutrient solution was supplied by subirrigation, by pumping it from waterproofed fiber containers of $1,000 \mathrm{~L}$ capacity. Each container provided the nutrient solution corresponding to the treatments for four troughs. Each container provided the nutrient solution corresponding to the treatments for four troughs (250 L for each one). The solution was pumped four times a day and one time in the middle of the night. It flooded the troughs until reaching $2 \mathrm{~cm}$ under the expanded clay surface, where a returning pipe was located. Another returning pipe was located in the base of each trough, and the returning flow was controlled by controlling its overture. It took 15 minutes to fill the troughs and about 20 minutes to drain it.

The experiment was arranged in a completely randomized design, with four replications. The plants were cultivated in a $100 \%$ of ionic strength vegetative growth solution containing: $8 ; 2 ; 4 ; 2 ; 1$; and $1 \mathrm{mmol} \mathrm{L}^{-1}$ of $\mathrm{N}, \mathrm{P}, \mathrm{K}$, $\mathrm{Ca}, \mathrm{Mg}, \mathrm{S}$ and $35 ; 19 ; 21 ; 4 ; 0.9$; and $0.7 \mu \mathrm{mol} \mathrm{L}^{-1}$ of $\mathrm{Fe}, \mathrm{Mn}, \mathrm{B}, \mathrm{Zn}, \mathrm{Cu}$, and $\mathrm{Mo}$, respectively. After emission of the first clusters, the nutrient solution was changed to fruiting formulation containing: 12; 3 ; $3 ; 1.5 ; 1.5 \mathrm{mmol} \mathrm{L}^{-1}$ of $\mathrm{N}, \mathrm{P}, \mathrm{Ca}, \mathrm{Mg}, \mathrm{S}$, and 59 ; $20 ; 25 ; 4 ; 1.3$ and $0.7 \mu \mathrm{mol} \mathrm{L}^{-1}$ of $\mathrm{Fe}, \mathrm{Mn}, \mathrm{B}, \mathrm{Zn}$, $\mathrm{Cu}$, and Mo, respectively. The treatments consisted of $\mathrm{K}$ supplied at the doses $6,8,10$, and $12 \mathrm{mmol} \mathrm{L}^{-1}$. These formulations were decribed by Fernandes et al. (2002).

The volume of the solution was monitored daily and replenished with water up to the initial volume of $1,000 \mathrm{~L}$ in each container. The solution $\mathrm{pH}$ was monitored and adjusted to $5.5-6.5$ with $\mathrm{HCl}$ or $\mathrm{NaOH}$. During all the tomato cycle periodic additions of nutrients the solutions were performed, according to the reduction of the electrical conductivity, admitting up to $30 \%$ depletion of the initial ECs, that varied from 1,5 to $1,7 \mathrm{dS} / \mathrm{m}$.

The plants were tied with string, conducted with two stems, and terminal buds pruned when each plant had three leaves above the fourth fruit cluster, leaving an average of 20 fruits per cluster when not branched. The branched clusters were left with 12 fruits per branch. Pruning took place during the experiment to control the number of fruits and removal of suckers.

Fruits were picked biweekly from the 26 DAT, with one plant taken from each treatment for growth analysis: the dry matter production of leaves, stems, roots, flowers, and fruits were measured.

The accumulated leaf area, root length, and root volume were determined by the method of water displacement in a graduated cylinder and used to calculate the growth ratios:

a) increase of total dry matter (Wt), leaves $(\mathrm{Wl})$, stem (Ws), and roots (Wr).

b) relative growth rate (RGR) - is the increase of dry mass per plant calculated by the equation: $\mathrm{RGR}=\mathrm{dW} / \mathrm{dt}$, where:

$\mathrm{dW}=$ increase of dry matter at time 2 less initial biomass at time 1 ;

$\mathrm{dt}=$ time 2 less time 1

c) rate assimilation liquid (RAR) - evaluates the dry mass production rate expressed per unit of total leaf area, as unit mass per unit area per unit of time given by the equation: $\mathrm{RAR}=(1 /$ Leaf Area $) \mathrm{x}$ (dW/dt).

d) leaf area ratio (LAR) - is the ratio of assimilatory material per unit of plant material present, expressed as units of area per unit mass calculated by the equation: LAR = Leaf area/W, where $\mathrm{W}$ is the total increase of plant dry matter.

e) leaf area index (LAI) - is the ratio between the total leaf area of the crop and the total area of ground surface, given by the equation: LAI = Leaf Area/Total Trough Area

f) root-shoot ratio (RSR) - is the balance between root and shoot growth over time.

Nutrient accumulation was also evaluated: nitrogen $(\mathrm{N})$, phosphorus $(\mathrm{P}), \mathrm{K}$, calcium $(\mathrm{Ca})$, magnesium $(\mathrm{Mg})$, and sulfur (S) in leaves, stems, and roots. The dried samples were weighed, ground, sieved, and digested by sulfur for the $\mathrm{N}$-analysis by the micro-Kjeldahl method. Another sub-sample was subjected to nitric-perchloric digestion and the $\mathrm{K}$ content was determined by flame photometry; $\mathrm{S}$ by sulfate turbidimetry, $\mathrm{Ca}$ and $\mathrm{Mg}$ were determined by atomic absorption spectrophotometry. 
The experiment was arranged in a completely randomized design. All combinations of the first factor composed of the six biweekly fruit pickings $(26,41,56,71,86$, and 101 days after transplanting - DAT) and the second factor corresponding to the four $\mathrm{K}$ doses $(6,8,10$ and 12 mmol L ${ }^{-1}$ ), with one plant as the experimental unit. The results were examined by analysis of variance and regression. The models were chosen based on $\mathrm{R}^{2}$, the significance of the coefficients (tested at the $5 \%$ level of significance by the $t$ test), and their biological significance. The equations were then adjusted to the means of the concentrations and their respective determination coefficients $\left(\mathrm{R}^{2}=\right.$ SSRegression/ SSTreatments) were calculated, with the regression coefficients significant by the $t$ test at $5 \%$ of probability.

\section{RESULTS}

No significant effect of $\mathrm{K}$ doses were found on the characteristics studied, only the picking time factor significantly influenced plant growth.

Figure 1 shows the primary growth variables, that is, phytomass (Wt) and leaf area. The Wt analysis showed a continuous growth over time, reaching a mean accumulation of $467.25 \mathrm{~g}$ dry matter per plant at 101 DAT (Figure 1A). A linear increase of leaf area occurred over time, reaching a mean of $23,024.79 \mathrm{~cm}^{2}$, at $101 \mathrm{DAT}$, due to the accumulation of phytomass (Figure 1B).
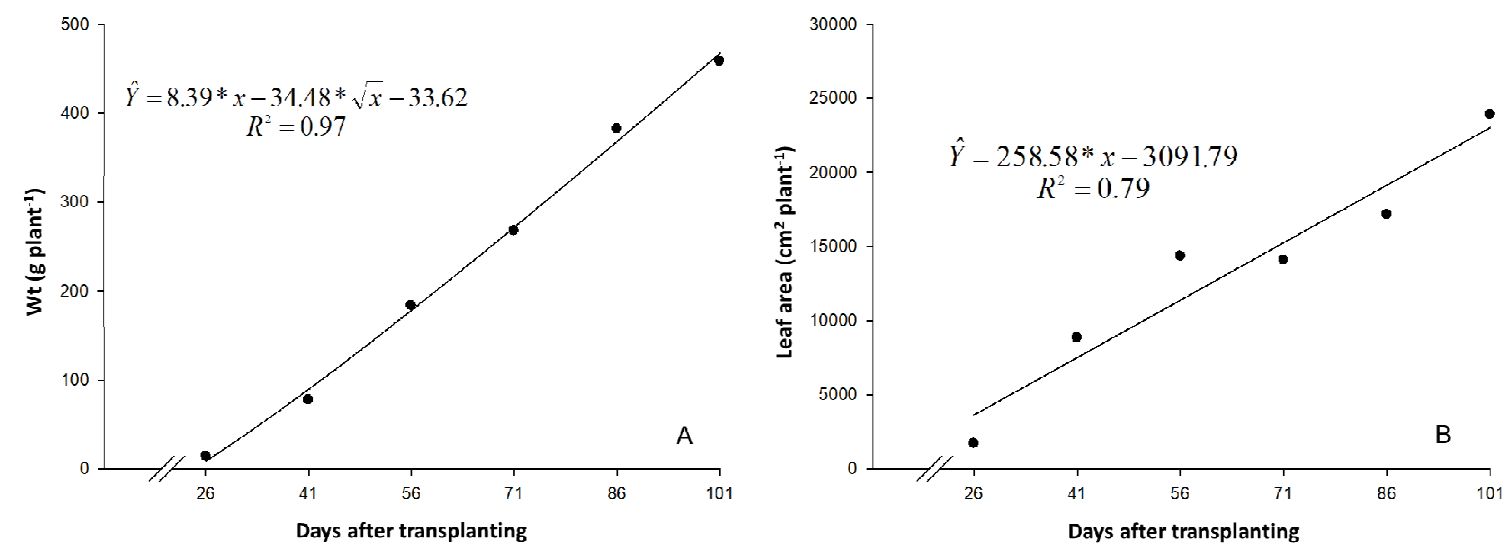

* Significant at $5 \%$ by t-test.

Figure 1. Total dry matter accumulation (Wt) (A) and leaf area (B) in cherry tomato plants grown in hydroponic subirrigation system.

In the present study, LAI followed the behavior of the leaf area, reaching 9.3 and 23,024.79 $\mathrm{cm}^{2}$, respectively, at 101 DAT (Figures 2A and 1B. However, leaf area ratio (LAR) decreased with plant growth (Figure 2B). Figure 2C shows a reduction in the net assimilation rate. The RGR, which is the main component of the increase in total plant dry matter, has gradually decreased over the growing period (Figure 2D).

The dry matter accumulation of leaves and stem of tomato plants as a function of time is shown in Figure 3. A linear increase in the leaf dry matter accumulation occurred throughout the evaluation period, and the same was found for the increase in dry matter of stems, reaching $107.15 \mathrm{~g}$ at $101 \mathrm{DAT}$ (Figure 3B).

Figure 4 presents the length of main root (RL), root dry matter accumulation (Wr), and root volume (RV). The root-shoot ratio was not influenced by time, ie, $\hat{\mathrm{Y}}=0.08$.
Flowering started at 20 DAT, increasing gradually and peaking at 68 DAT with 103.92 flowers (Figure 5A). The number of fruits increased until the end of the evaluation period (Figure 5B). The dry matter production of flowers (Figure 5C) showed a quadratic adjustment with maximum point at 58.25 DAT, with $1.38 \mathrm{~g}$ of flowers. The fruit dry matter (FDM) presented a potential adjustment, thus, the increase in the number and development of fruits provided increases in the accumulation of fruit dry matter over time. 

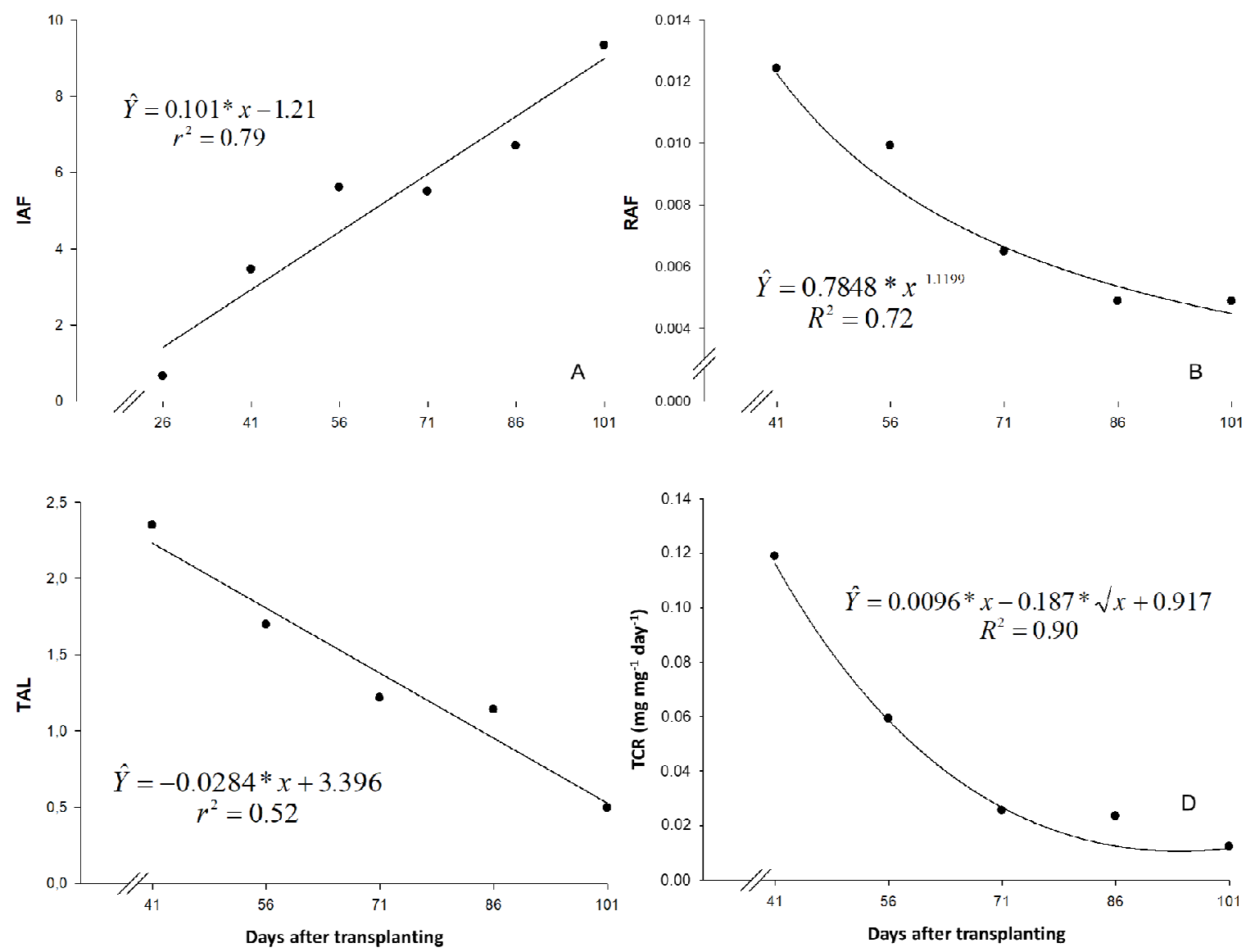

* Significant at $5 \%$ by t-test.

Figure 2. Leaf area index (A), leaf area ratio (B), net assimilation rate (C), and relative growth rate (D) in cherry tomato grown in hydroponic subirrigation system.
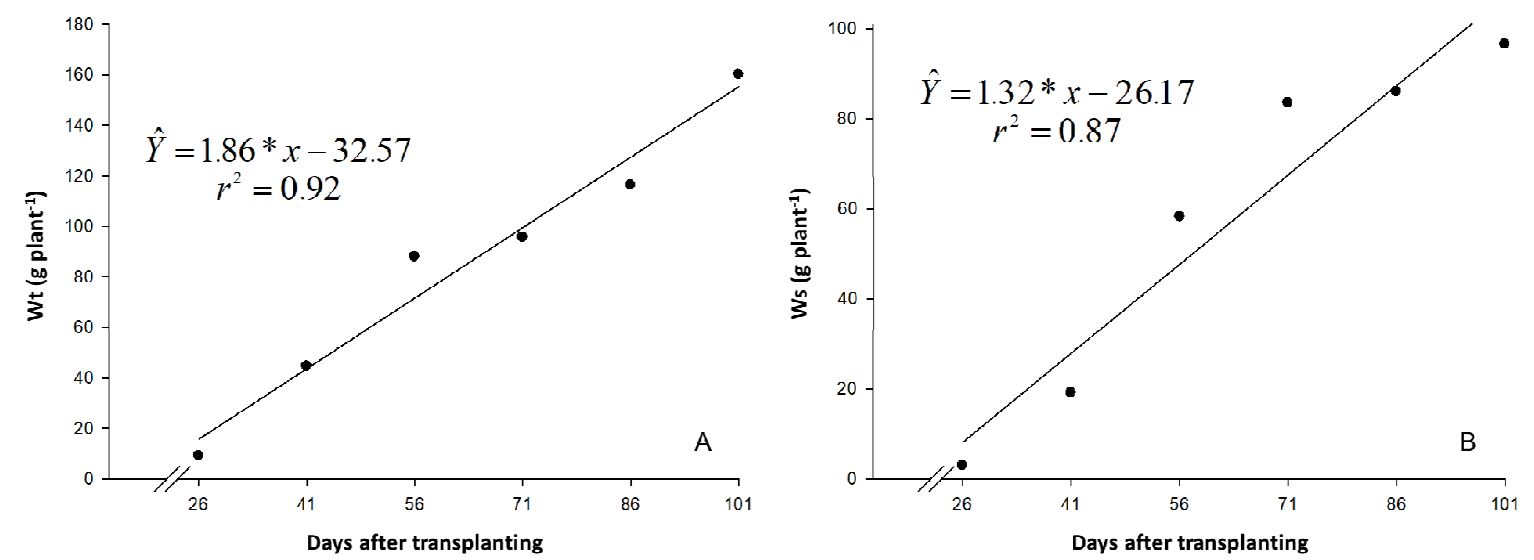

* Significant at $5 \%$ by t-test.

Figure 3. Dry matter accumulation of leaves (A) and stem (B) in cherry tomato plants grown in hidroponic subirrigation system. 

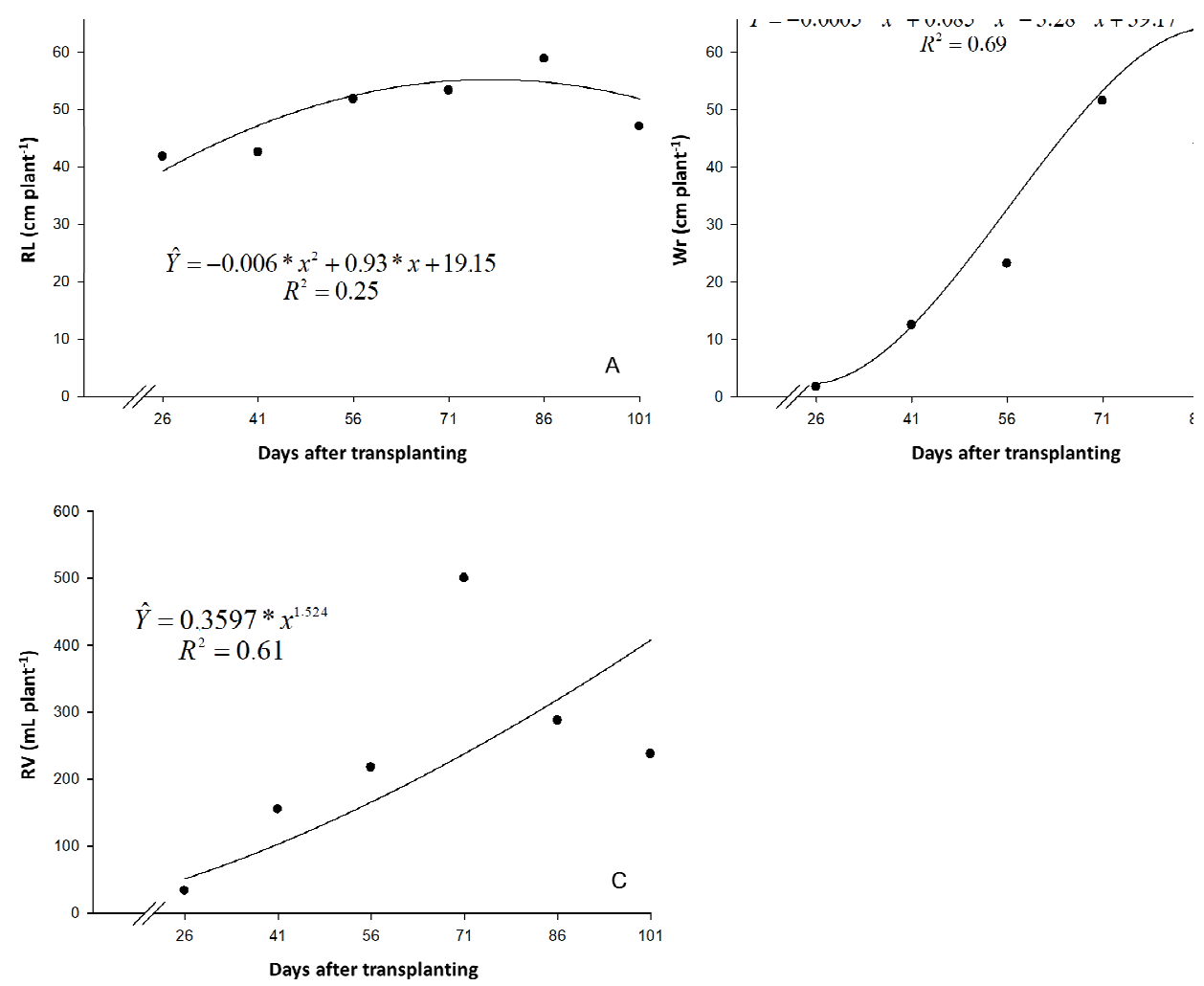

* Significant at $5 \%$ by t-test.

Figure 4. Root length (A), dry matter accumulation of roots (B) and root volume (C) in cherry tomato plants, cultivated under hidroponic irrigation system.
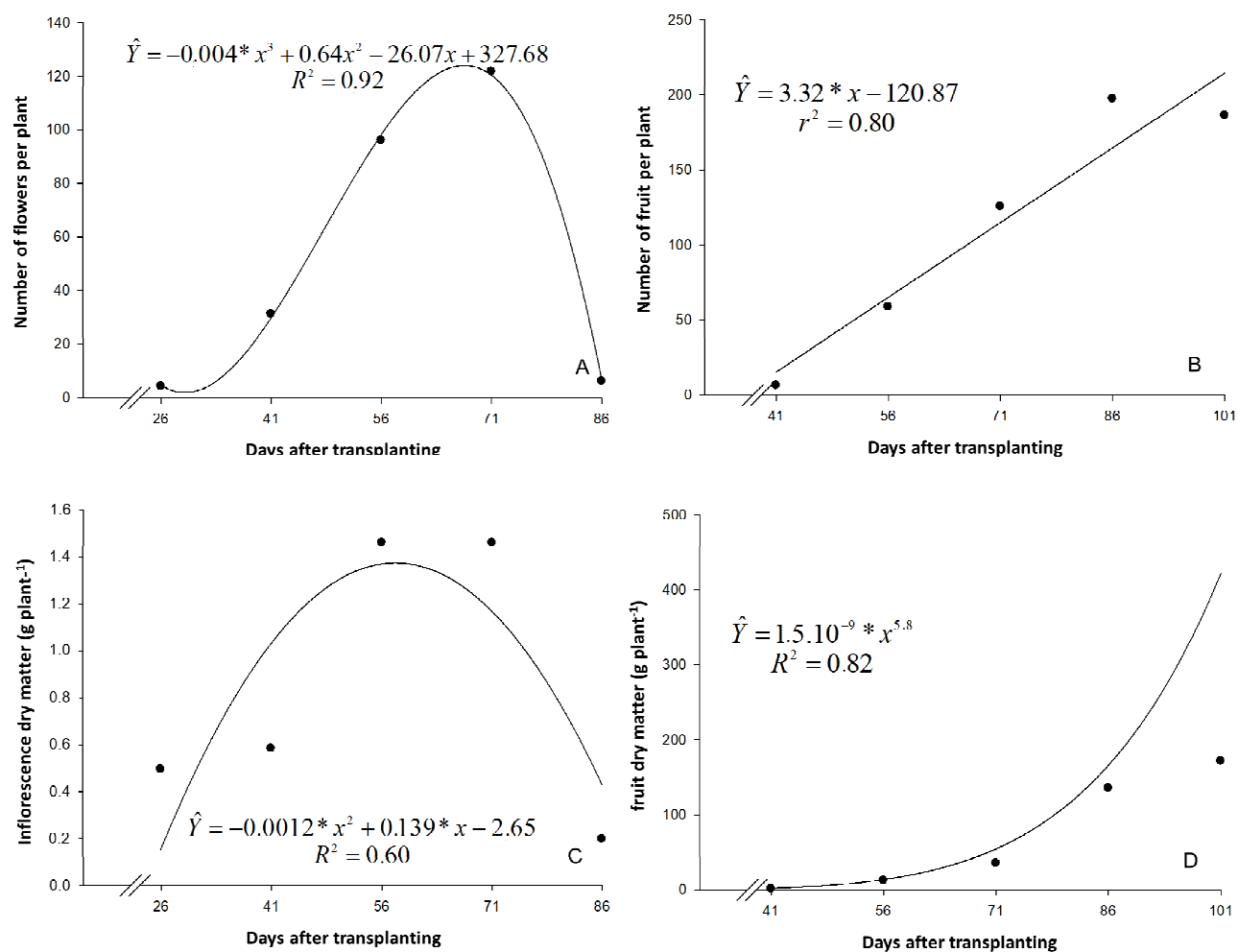

* Significant at $5 \%$ by t-test.

Figure 5. Number of flowers (A), number of fruits (B), dry matter of flowers (C) and fruits (D) in cherry tomato grown in hydroponic subirrigation system. 
Effect of potassium...

Only the accumulation of $\mathrm{N}, \mathrm{K}, \mathrm{Ca}$, and $\mathrm{Mg}$ was influenced by time. It increased from 41 DAT up to the end of the evaluations. The amount of $\mathrm{N}$ accumulated in the leaves was $4850 \mathrm{mg}$ per plant at 101 DAT (Figure 6A). Leaves and stem accumulated $\mathrm{P}$ in a linear trend, reaching 35.35 and $35.47 \mathrm{mg}$ per plant, respectively, at $101 \mathrm{DAT}$ (Figure 6B). $\mathrm{P}$ accumulation in the roots was
MAIA, J. T. L. S. et al

adjusted to a potential model reaching $17.43 \mathrm{mg}$ per plant at 101 DAT. The maximum increase of $\mathrm{K}$ in the leaves also occurred at 101 DAT, accumulating $928.17 \mathrm{mg}$ per plant (Figure 6C). A linearly adjusted increase occurred in $\mathrm{Ca}$ accumulation in leaves and stems of the tomato plants, accumulating 828.39 and $167.42 \mathrm{mg}$ per plant, respectively, at $101 \mathrm{DAT}$ (Figure 6D).
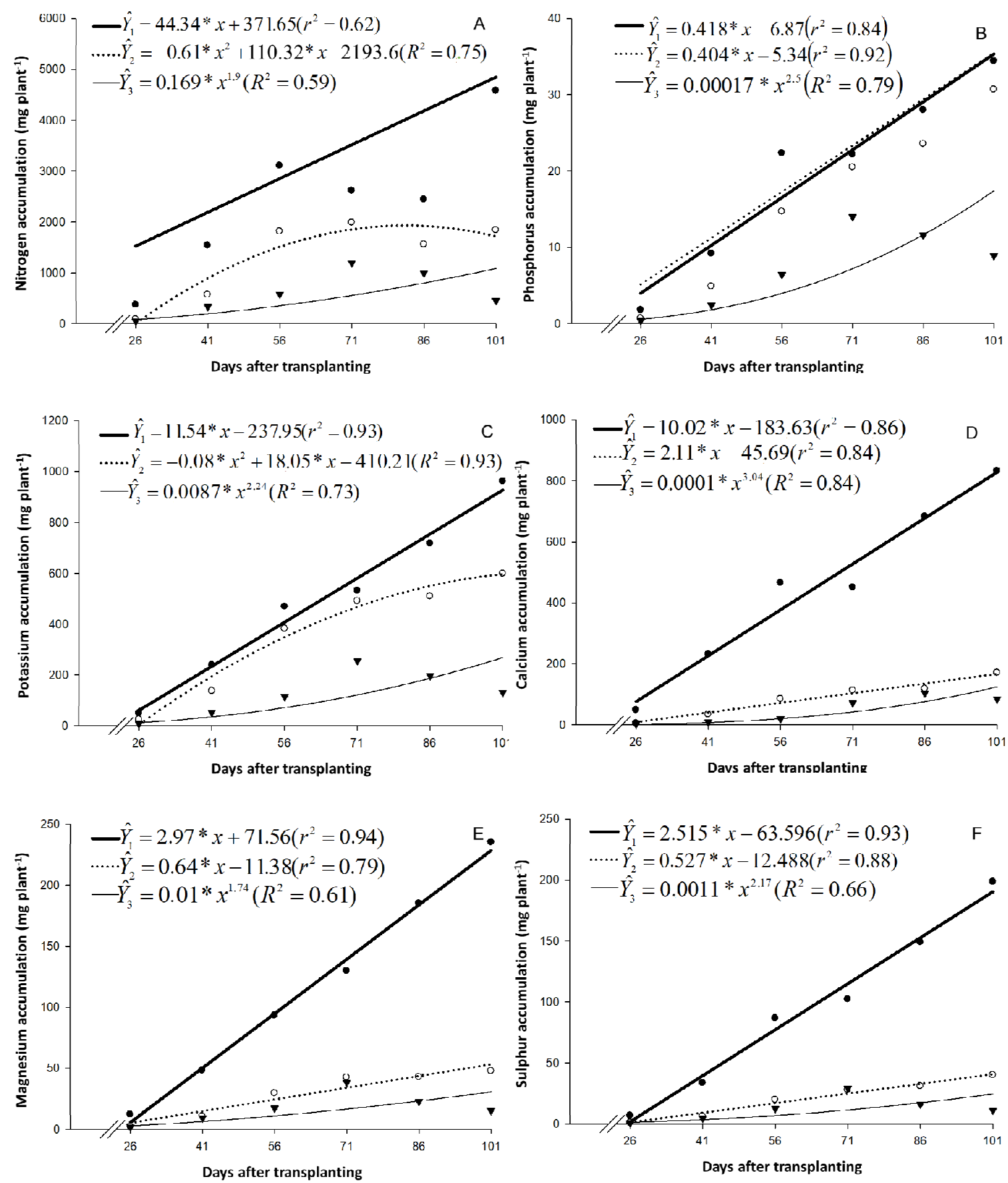

* Significant at $5 \%$ by t-test

Figure 6. Nitrogen (A), phosphorus (B), potassium (C), calcium (D), magnesium (E), and sulfur (F) accumulation in leaves $(\hat{Y} 1)$, stem $(\hat{Y} 2)$, and roots $(\hat{Y} 3)$ in cherry tomato grown in hydroponic subirrigation system. 


\section{DISCUSSION}

In relation to a leaf area, Fayad et al. (2001) reported in EF-50 hybrids, that both leaf area and leaf number increased up to 93 and 81 days, respectively, after transplanting, whereas in this study, the plants still had not presented a decrease in phytomass accumulation up to 101 days.

The slower initial growth is expected, since the plants generally have sigmoid growth and dry matter accumulation, that is, with a slow initial phase due to the small carbon assimilation due to the small leaf area. Rocha (2009) observed a lower accumulation of dry matter mass $\left(254 \mathrm{~g} \mathrm{plant}^{-1}\right)$ and lower leaf area $\left(4166 \mathrm{~cm}^{2}\right)$ for Cherry Red, of the Blue Line, in hydroponic cultivation.

It is known that as leaf area increases, leaf area index (LAI) also increases to a point from which self-shading will compromise photosynthetic efficiency. In the present study, LAI followed the behavior of the leaf area much higher values than those found in other studies (PIVETTA et al., 2007; ROCHA, 2009). However, leaf area ratio (LAR) decreased with plant growth. This can be explained both by the increase in leaf drop and the reduction of photoassimilate production to form new leaves (COSTA et al., 1989), as well as the increase in selfshading. In tomatoes pruned at the first bunch, LAR also decreased during the crop cycle (GUIMARÃES et al., 2009), that is, more photosassimilates were directed to the reproductive parts to the detriment of leaf production. Rocha (2009) reported that LAR decreased until 50 DAT in cherry tomato var. Cherry Red grown in hydroponic system during the cycle summer-autumn 2008, indicating the progressive decrease of photoassimilates directed toward the leaves.

There was a reduction in the net assimilation rate. This is possibly due to the marked increase in leaf area (Figure 1B), since NAR is influenced by leaf area index, solar radiation, water balance, and internal conditions of the plant (CONCEIÇÃO et al., 2005). The leaf expansion favors self shading and the efficiency of the assimilation system is negatively affected, compromising the photosynthetic activity, seeing that the NAR is an estimate of the liquid photosynthesis. Moreover, when the fruit sink capacity increases, the photoassimilates are preferentially directed toward these organs to the detriment of the assimilatory tissues (GUIMARÃES et al., 2009).

RGR is the product between NAR and LAR, thus, a continuous decrease in LAR can cause a subsequent reduction in NAR and thereby compromise the RGR of the plant. As the plant accumulates dry matter, it needs to increase photoassimilate production for organ maintenance, reducing growth, which is shown by RGR (BENINCASA, 2003). The RGR in tomato whose first cluster was pruned peaked at 74 days after emergence, when there were more assimilatory tissues in the plant (GUIMARÃES et al., 2009). Rocha (2009) found maximum RGR in cherry tomato plants at the initial stage of cultivation, then it gradually decreased and reached $0.017 \mathrm{~g} \mathrm{~g}^{-1}$ day $^{-1}$ at the end of the experiment, whereas in this study, the RGR was $0.035 \mathrm{~g} \mathrm{~g}^{-1}$ day $^{-1}$.

Despite the beginning of fruit ripening, around 101 DAT, the accumulation of dry matter in the leaves had not stabilized, that is, the senescence phase of the plant occurred after this period. Rocha (2009) observed in cherry tomatoes cultivated in the summer-fall cycle that the leaves besides being main sources are strong photoassimilate sinks. Plants of cultivar Kyndio showed maximum dry matter yield of leaves at 114 DAT, for both treatments applied: with pruning or without pruning of the first cluster (GUIMARÃES et al., 2009).

RL showed little variation because of the limited space for root growth. However, $\mathrm{Wr}$ and $\mathrm{Vr}$ increased over the evaluation period, indicating the ability of the roots to explore the substrate horizontally, since they were limited in depth by the height of the troughs. The accumulation of root dry matter peaked at 88.67 DAT with $68.06 \mathrm{~g}$. The root volume was $407.87 \mathrm{~mL}$ at 101 DAT.

As for the development of the fruits in the work of Lopes et al. (2011) found accelerated growth of fruit dry matter mass for 'SM-16' tomato grown under different soil covers, from 42 DAT to 84 DAT, just after a less intense growth.

In relation to the accumulation of $\mathrm{N}, \mathrm{K}, \mathrm{Ca}$, and $\mathrm{Mg}$, there was increase of $\mathrm{N}$ in the stem with quadratic adjustment, peaking at $82 \mathrm{DAT}$ and accumulating $1,931 \mathrm{mg}$. At $101 \mathrm{DAT}$, the $\mathrm{N}$ accumulation in the roots was $1,086.62 \mathrm{mg}$ per plant. In tomato cultivar Raissa, the accumulation of $\mathrm{N}$ and $\mathrm{K}$ increased throughout the crop cycle (PRADO et al., 2011).

Because the evaluations ended at the beginning of the maturation phase and the nutrient solution applied from the beginning of the reproductive phase had increasing $\mathrm{K}$ doses, the line of the linear regression shows that the accumulation of $\mathrm{K}$ remained continuous in the leaves. $\mathrm{K}$ plays essential functions in the plants such as in photosynthesis, protein synthesis, enzymatic activation, and carbohydrate transport (TAIZ and ZEIGER, 2013), therefore, leaves are the organs 
that, in the vegetative phase, require most of this nutrient. Following this phase, $\mathrm{K}$ tends to favor the transport of carbohydrates toward the fruits, evidencing its greater accumulation in fruits, as in other fruit vegetables (FAYAD, 2001; GRANGEIRO; CECÍLIO FILHO, 2005). The accumulation of $\mathrm{K}$ in the stem showed increase with quadratic adjustment, and in the roots, potential adjustment, reaching $268.66 \mathrm{mg}$ per plant, at 101 DAT.

A linearly adjusted increase occurred in $\mathrm{Ca}$ accumulation in leaves and stems of the tomato plants. The movement of the $\mathrm{Ca}$ through xylem, following the transpiration stream, allows greater accumulation of this nutrient in the aerial part. However, in this study, the accumulated quantities were much lower than those found in the Raissa tomato, about $2 \mathrm{~g}$ per plant at 85 DAT (PRADO et al., 2011). Bivalent cations such as $\mathrm{Ca}$ and $\mathrm{Mg}$ are more retained in the apoplast due to the interaction with the electric charges present, which may be the cause of the lower translocation and, consequently, less accumulation in the dry matter. Competition between cations at high doses of $\mathrm{K}$ may also be a cause for this result.

The maximum accumulation of $\mathrm{Mg}$ in leaves and stems with linear adjustment was 228.41 and $53.26 \mathrm{mg}$ per plant, respectively, at 101 DAT. In the roots, there is an increase with potential adjustment, reaching $30.73 \mathrm{mg}$ per plant, at 101 DAT. In Raissa tomato, the accumulation of $\mathrm{Mg}$ in the plant was $0.68 \mathrm{~g}$, with partitioning among leaves, stem, and roots of 55 and $3 \%$, respectively (PRADO et al., 2011). The adjustment in the accumulation of sulfur in the leaves and stem was linear, reaching maximum values of 190.42 and $40.74 \mathrm{mg}$ per plant, respectively, at 101 DAT. A potential adjustment was found for the roots, accumulating $24.59 \mathrm{mg}$ per plant at $101 \mathrm{DAT}$.

\section{CONCLUSIONS}

$\mathrm{K}$ doses between 6 and $12 \mathrm{mmol} \mathrm{L}^{-1}$ had no influence on the growth of the cherry tomato.

The relative growth rate decreased gradually over the evaluation period.

The accumulation of $\mathrm{N}, \mathrm{P}, \mathrm{K}, \mathrm{Ca}, \mathrm{Mg}$, and $\mathrm{S}$ in the leaves peaked at $101 \mathrm{DAT}$, accumulating 4,$850 ; 35.35 ; 928.17 ; 828.39 ; 228.41$; and 190.42 $\mathrm{mg}$, respectively.

\section{ACKNOWLEDGMENTS}

The authors thank the National Council for Scientific and Technological Development (CNPq) for the financial support and CAPES for granting the doctoral scholarship.

RESUMO: O potássio tem grande impacto no crescimento de plantas, regulando reações de síntese e participando na translocação de fotoassimilados, elongação celular e reações enzimáticas relacionadas à fotossíntese, respiração, síntese de amidos, proteínas e lignina. Assim, objetivou-se com este trabalho caracterizar o crescimento das plantas de tomateiro cereja em sistema hidropônico, sob doses crescentes de potássio. O delineamento experimental foi inteiramente casualizado, com quatro repetições. Os tratamentos consistiram das diferentes doses de potássio $\left(6,8,10\right.$ e $\left.12 \mathrm{mmol} \mathrm{L}^{-1}\right)$ e das datas de coletas aos 26, 41, 56, 71, 86 e 101 DAT (dias após o transplantio). Em cada coleta determinou-se o acúmulo de massa seca de folhas, caules, raízes, inflorescências e frutos; área foliar; número de inflorescências e frutos; comprimento e volume radicular. Calcularam-se os índices fisiológicos: taxa de crescimento relativo, razão e índice de área foliar, taxa assimilatória líquida e razão raiz-parte aérea e acúmulo dos nutrientes nas folhas, caules e raízes. Doses de potássio entre 6 e $12 \mathrm{mmol} \mathrm{L}^{-1}$ não influenciaram o crescimento do tomateiro tipo cereja. A taxa de crescimento relativo reduziu-se gradativamente ao longo do período de avaliação. Os acúmulos de nitrogênio, fósforo, potássio, cálcio, magnésio e enxofre nas folhas foram máximos aos 101 DAT.

PALAVRAS-CHAVE: Solanum lycopersicum L. Solução nutritiva. Análise de crescimento. Subirrigação.

\section{REFERENCES}

ARAÚJO, L.; SILVA, K. J. P.; LEMOS, L. M. C.; MILAGRES, C. C.; CARDOSO, D. S. C. P.; ALVES, L. C.; PEREIRA, P. R. G. Tomate cereja cultivado em diferentes concentrações de solução nutritiva no sistema hidropônico capilar. Unimontes Científica, v. 15, n. 1, p. 18-27, 2013. 
BARRETO, L. P.; BEZERRA NETO, E. O potássio no metabolismo vegetal. Recife: UFRPE, 2000. 58p.

BENINCASA, M. M. P. Análise de crescimento de plantas: noções básicas. Jaboticabal: FUNEP, 2003. 42p.

CONCEIÇÃO, M. K.; LOPES, N. F.; FORTES, G. R. L. Análise de crescimento de plantas de batata-doce (Ipomea batatas (L.) LAM) cultivares Abóbora e da Costa. Revista Brasileira de Agrociência, v. 11, n. 3, p. 273-278, 2005.

COSTA, P. C.; CAÑIZARES, K. A. L.; GOTO, R. Produção de pepino de plantas enxertadas cultivadas em soluções nutritivas com diferentes teores de potássio. Horticultura Brasileira, v. 19, n. 3, p. 207-209, 2001. https://doi.org/10.1590/S0102-05362001000300010

COSTA, R. C. L.; LOPES, N. F.; OLIVA, M. A.; BARROS, R. S. Crescimento e conversão de energia solar em feijão submetido a três doses de nitrogênio e dois regimes hídricos. Pesquisa Agropecuária Brasileira, v. 24, n. 12, p. 1439-1450, 1989.

FAYAD, J. A.; FONTES, P. C. R.; CARDOSO, A. A.; FINGER, L. F.; FERREIRA, F. A. Crescimento e produção do tomateiro cultivado sob condições de campo e de ambiente protegido. Horticultura Brasileira, v. 19, n. 3, p. 232-237, 2001. https://doi.org/10.1590/S0102-05362001000300016

FERNANDES, A. A.; MARTINEZ, H. E. P.; FONTES, P. C. R. Produtividade, qualidade dos frutos e estado nutricional do tomateiro tipo longa vida conduzido com um cacho, em cultivo hidropônico, em função das fontes de nutrientes. Horticultura Brasileira, v. 20, n. 4, p. 564-570, 2002. https://doi.org/10.1590/S010205362002000400011

GENUNCIO, G. C., SILVA, R. A. C., SÁ, N. A. M., ARAÚJO, A. P. Produção de cultivares de tomateiro em hidroponia e fertirrigação sob razões de nitrogênio e potássio. Horticultura Brasileira, v. 28, n. 1, p. 446-452, 2010. https://doi.org/10.1590/S0102-05362010000400012

GOMES, J. V. S.; DIAS, N. S.; OLIVEIRA, A. M.; BLANCO, F. F.; SOUZA NETO, O. N. Crescimento e produção de tomate cereja em sistema hidropônico com rejeito de dessalinização. Revista Ciência

Agronômica, v. 42, n.4, p. 850-856, 2011. https://doi.org/10.1590/S1806-66902011000400005

GRANGEIRO, L. C.; CECÍLIO FILHO, A. B. Acúmulo e exportação de macronutrientes em melancia sem sementes. Horticultura Brasileira, v. 23, n.3, p. 763-767, 2005. https://doi.org/10.1590/S010205362005000300015

GUIMARÃES, M. A.; SILVA, D. J. H.; PETERNELli, L. A.; FONTES, P. C. R. Distribuição de fotoassimilados em tomateiro com e sem a retirada do primeiro cacho. Bioscience Journal, v. 25, n. 5, p. 8392, 2009.

HUNT, R. Basic growth analysis. London: Unwin Hyman, 1990. 112p. https://doi.org/10.1007/978-94-0109117-6

JORGE, Y.; GONZÁLEZ, F. Estimación Del área foliar em los cultivos de ají y tomate. Agrotecnia de Cuba, v. 27 , n. 1 , p. 123-126, 1997.

LOPES, W. A. R.; NEGREIROS, M. Z.; DOMBROSKI, J. L. D.; RODRIGUES, G. S. O.; SOARES, A. M.; ARAÚJO, A. P. Análise do crescimento de tomate 'SM-16' cultivado sob diferentes coberturas de solo.

Horticultura Brasileira, v. 29, n. 1, p. 554-561, 2011. https://doi.org/10.1590/S0102-05362011000400019

MARENCO, R. A.; LOPES, N. F. Fisiologia Vegetal: fotossíntese, respiração, relações hídricas e nutrição mineral. Viçosa: Editora UFV, 2005. 451p. 
PIVETTA, C. R.; TAZZO, I. F.; MAASS, G. F.; STRECK, N. A.; HELDWEIN, A. B. Emissão e expansão foliar em três genótipos de tomateiro (Lycopersicon esculentum Mill.). Ciência Rural, v. 37, n. 5, p. 12741280, 2007. https://doi.org/10.1590/S0103-84782007000500009

PRADO, R. M.; SANTOS, V. H. G.; GONDIM, A. R. O.; ALVES, A. U.; CECÍlIO FILHO, A. B.;

CORREIA, M. A. R. Crescimento e marcha de absorção de nutrientes em tomateiro cultivar Raissa cultivado em sistema hidropônico. Semina: Ciências Agrárias, v. 32, n. 1, p. 19-30, 2011. https://doi.org/10.5433/1679$0359.2011 \mathrm{v} 32 \mathrm{n} 1 \mathrm{p} 19$

ROCHA, M. Q. Crescimento, fenologia e rendimento do tomateiro cereja em cultivo hidropônico. 2009. 129 f. Dissertação (Mestrado do Programa de pós-graduação em Sistemas de. Produção Agrícola Familiar), Universidade Federal de Pelotas, Rio Grande do Sul, 2009.

RODRIGUES, M. B.; DORNELLES, A. L. C.; SILVA, V. O. M. Z.; PESSOA, C. A.; SERRALHA, B. C. S.; SILVA, D. A. G.; PEREIRA, M. B. Caracterização morfológica de 25 cultivares de tomateiro tipo cereja caracteres da planta. Horticultura Brasileira, v. 26, n. 1, p. 2261-4467, 2008.

SANGTARASHANI, E. S.; TABATABAEI, S. J; BOLANDNAZAR, S. Yield, Photosynthetic efficiency and Quality parameters of Cherry tomato as affected by $\mathrm{Ca}^{2+}$ and $\mathrm{K}^{+}$under $\mathrm{NaCl}$ salinity. International Journal of Agriculture and Crop Sciences, v. 5, n. 1, p.1280-1288, 2013.

SANTOS, A. N.; SILVA, E. F. F.; SILVA, G. F.; BARNABÉ, J. M. C.; ROLIM, M. M.; DANTAS, D. C. Yield of cherry tomatoes as a function of water salinity and irrigation frequency. Revista Brasileira de Engenharia Agrícola e Ambiental, v. 20, n. 2, p. 107-112, 2016. https://doi.org/10.1590/18071929/agriambi.v20n2p107-112

TAIZ, L.; ZEIGER, E. Fisiologia Vegetal. 5a Ed. Artmed, Porto Alegre, 2013. 918p. 